レーザー解説

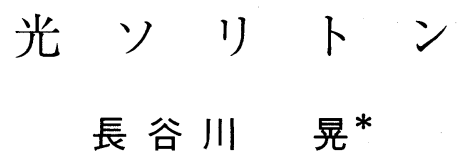

(1994年1月22日＼cjkstart受理)

\title{
Optical Soliton
}

\section{Akira HASEGAWA*}

(Received January 22, 1994)

There is an increased interest in the communication system based on the optical soliton of the light wave envelope in a fiber. In fact soliton systems have achieved record error-free transmission both in speed and distance in fibers. This paper reviews the physics of optical solitons and characteristics of soliton based communication systems.

Key Words: Optical soliton.

\section{1. まえがき}

レーザー光のコヒーレントな性質を用いた光 通信はレーザーの発見当時から色々提案されて きた，しかし空気中では減衰が大きいことから 宇宙での通信を除き，レーザー光通信には何ら かの導波路を必要とする。ガラスファイバーを 用いた誘電体導波路は減衰率がレーレイ散乱の 理論値にほぼ近いところまで改良され, 光通信 の基本的媒体となっている。さらに1987年に開 発されたエルビウムをドープしたファイバー光 増幅器(EDFA)はファイバー導波路を実質的に 無損失のものにした。この結果, 光波の長距離 伝送に残された問題はファイバーの持つ分散特 性(主に群速度分散性)とカー効果からくる非線 形性となった。これらの効果はパルス状の光波 のパルス幅と振幅によって決り, パルス幅が大
きいと非線形効果が，パルス幅が小さいと分散 効果が問題となる。変調を受けた連続光波の場 合にはスペクトルの幅がパルス幅の逆数に相当 するから，変調周波数が大きいと同様に分散効 果が問題となる。

通常のファイバーではファイバー損失が最小 となる波長, 約 $1.5 \mu \mathrm{m}$ で群速度分散Dはほぼ1 ないし10 ps/nm·kmで与えられる。この結果波 長 $1 \mathrm{~nm}$ で変調を受けた光波は $1 \mathrm{~km}$ 走ると1ない し 10 ps 程度の分散拡がりを伴う。一方非線形 性は自己収束性をもたらすため分散によるパル スの拡がりを除く効果を持つ。ファイバーの光 ソリトンはこの効果を用いて作られた安定な定 常パルスのことをいう。

ファイバー中の光波の包絡線がファイバーの 分散性及びカー効果による非線形性のバランス によりソリトンを作る可能性は，1973年，長谷 


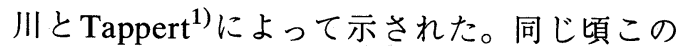
ソリトン解を示す非線形シュレディンガー方程 式が積分可能であり，その基本解がソリトンで 記述出来ることがZakharovとShabat ${ }^{2)}$ によって 示された。しかし当時, 損失の少ないファイバー も, 必要な光源も存在しなかったため, 光りリ トンの実験的な確認には7年の日時を必要とし た。

1980年, Mollenauerら ${ }^{3)}$ は光源にモードロッ クされたカラーセンターレーザーを用い, $700 \mathrm{~m}$ の低損失ファイバー中に幅 $7 \mathrm{pc}$ 光パル スを伝送させ, 出力側のパルス幅が入力電力を 増加することによって狭まることにより，ソリ トンの存在を確認した。

ソリトンは分散性と非線形性のバランスで発 生するため, ファイバーに損失があると, 波動 の振幅が減少し非線形性が弱まり, この結果, 分散性によるソリトン波形の拡がりが発生す る。従ってファイバー損失のためファイバー中 の光波の包絡線ソリトンは, そのパルス幅を 徐々に広げながら伝搬することになる。これを 防ぐためには, 適当な光増幅器をファイバー中 に挿入することにより，振幅を元通りの值に戻 してやらなければならない。

1980年前半に長谷川は児玉と共に, 損失によ る波形修正をしながらソリトンを高速通信に応 用する方法を次々に提案した $4,5,6)$

しかし、ソリトンの振幅を増幅器で急に持ち 上げると, 増幅器を通した後のパルスは入力側 のソリトンとは別のソリトンとなる。このため 出来るだけ擾乱を少なくする必要が生じ, 増幅 器の間隔を充分小さくしなければならないこと

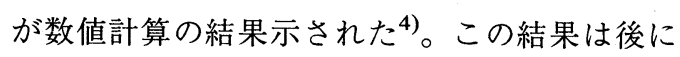
なり実験的に確証され, さらに理論的な裏づけ がなされることになった。

1980年には, 希土類のエルビウム元素をファ イバーにドープすることにより.ファイバーその ものを光増幅器に出来ることが証明され, しか も増幅率が最大となる波長が $1.55 \mu \mathrm{m}$ と丁度 ファイバーの損失が最小となる波長にあること がわかった ${ }^{7,8)}$ 。中沢ら ${ }^{9)}$ は, このエルビウム
ファイバー増幅器(EDFA)を用いたソリトンの 長距離伝送実験に初めて成功した。この結果, EDFAの出現はソリトンの高速通信への実用化 に大きな進展を与えることになる。

1990年代に入るとEDFAを用いたソリトンに よる超高速, 超長距離通信の実験結果が次々と

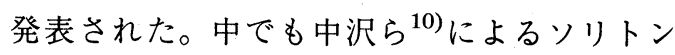
の周回実験を用いた 100 万 $\mathrm{km}$ 伝送の実験，お

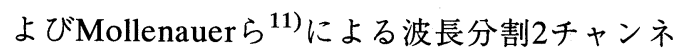
ルの $10 \mathrm{~Gb} / \mathrm{s}$ の $11,000 \mathrm{~km}$ の伝送実験はソリト ン通信の実用性を摇るぎないものにしたといえ よう。この後, Mollenauerら ${ }^{12)}$ はスライディ ングフィルターを用いて, 波長分割 2 チャンネ ルの $20 \mathrm{~Gb} / \mathrm{s}$ の $13,000 \mathrm{~km}$ の伝送実験にも成功し ている。

\section{2. 光ソリトンの理論}

2.1 ファイバー中の光波包絡線を表す非線 形シェレディンガー方程式

まず, ファイバー中の光波の包絡線関数が満 たす発展方程式を導こう。導波路の効果は後に 考えることにし，まず，カー効果を持つ誘電体 中の平面波の包絡線関数 $q(z, t)$ が満たす方程式 を考えよう。カー媒質中の屈折率 $n\left(\omega,|E|^{2}\right)$ は

$$
n\left(\omega,|E|^{2}\right)=n_{0}(\omega)+n_{2}|E|^{2}
$$

と書くことが出来る。カー効果は電子の非線形 応答により発生するため, 光の振動領域でも (1)式の瞬時応答で書くことが出来ることに注 意する。(1)式で $n_{0}(\omega)$ は屈折率の線形部分で一 般には分散性のため光波の角周波数 $\omega$ の関数と なる。 $n_{2}$ はカー効果と呼ばれガラスでは $1.3 \times$ $10^{-22}\left(\mathrm{~m} / \mathrm{V}^{2}\right)$ の值を持つ。 $|E|$ は電場の複素実 効振幅の絶対值を表す。平面波を仮定した光波 の電場 $E(z, t)$ は $x$ または $y$ 成分のみを持ち, 複素 振幅 $q(z, t)$ を用い

$$
E(z, t)=\operatorname{Re}\left[q(z, t) e^{i\left(k_{0} z-\omega_{0} t\right)}\right]
$$

と書くことが出来る。ここに $k_{0}, \omega_{0}$ はそれぞれ 搬送波の波数および角周波数を表し, $q(z, t)$ は 
位相の変化に比べゆっくりと変化する振幅を表 す。屈折率の定義から, 光波の波数 $k$ と角周波 数 $\omega$ の間には(1)より

$$
k=\frac{\omega}{c} n=\frac{\omega}{c} n_{0}(\omega)+\frac{\omega}{c} n_{2}|E|^{2}
$$

の関係が成り立つ。 $q(z, t)$ の満たす発展方程式 を導くため $k$ を搬送波の波数 $k_{0}$ の周りにテー ラー展開をしてみよう。

$k-k_{0}=k_{0}^{\prime}\left(\omega-\omega_{0}\right)$

$+k_{0}^{\prime \prime} \frac{\left(\omega-\omega_{0}\right)^{2}}{2}+\frac{\partial k}{\partial|E|^{2}}|E|^{2}+\frac{\mathrm{i} \omega_{0}}{c} \operatorname{Im}\left(n_{0}\right)$

$=k_{0}^{\prime}\left(\omega-\omega_{0}\right)+k_{0}^{\prime \prime} \frac{\left(\omega-\omega_{0}\right)^{2}}{2}+\frac{\omega_{0}}{c} n_{2}|E|^{2}+\mathrm{i} \gamma$

ここに

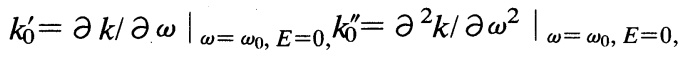

を表し, $\gamma=\omega_{0} \operatorname{Im}\left(n_{0}\right) / c$ は誘電体損失による光 波振幅の減衰率を表す。今ゆっくり变化する振 幅 $q$ を

$q(z, t)=\frac{1}{(2 \pi)^{2}} \int_{-\infty}^{\infty} \int_{-\infty}^{\infty} \bar{q}(K, \Omega) \mathrm{e}^{\mathrm{i}(K z-\Omega t)} d k d \Omega$

で表し， $K$ および $\Omega$ を搬送波の波数 $k_{0}$ および角 周波数 $\omega_{0}$ からわずかなずれを表すと考えると

$$
\begin{aligned}
& \frac{\partial q}{\partial z}=\mathrm{i} K q=\mathrm{i}\left(k-k_{0}\right) q \\
& \frac{\partial q}{\partial t}=\mathrm{i} \Omega q=-\mathrm{i}\left(\omega-\omega_{0}\right)
\end{aligned}
$$

と書くことが出来るから,$\left(k-k_{0}\right) \rightarrow \mathrm{i} \partial / \partial z$, $\left(\omega-\omega_{0}\right) \rightarrow \mathrm{i} \partial / \partial t$ なるオペレータと考え，(4)式 を実空間のオペレータで書いて $q(z, t)$ にオペ レートすると

$$
\begin{gathered}
\mathrm{i}\left(\frac{\partial q}{\partial z}+k_{0}^{\prime} \frac{\partial q}{\partial t}\right)-\frac{k_{0}^{\prime \prime}}{2} \frac{\partial^{2} q}{\partial t^{2}} \\
+\frac{\omega_{0} n_{2}}{c}|q|^{2} q=-\mathrm{i} \gamma_{q}
\end{gathered}
$$

(8) で与えられる。
を得る。(8)式で第1項の括弧の中は $q$ が群速度 で平行移動する効果を表すから，群速度に乗っ た座標での時間 $t$ で $t$ を表すことにより， $z$ 微分 のみで書くことが出来る。すなわち， $t^{\prime}=t-k_{0}^{\prime}$ $z$ で $t$ 置き換えると(8)式は

$$
\mathrm{i} \frac{\partial q}{\partial z}-\frac{k_{0}^{\prime \prime}}{2} \frac{\partial^{2} q}{\partial t^{\prime 2}}+\frac{\omega_{0} n_{2}}{c}|q|^{2} q=-\mathrm{i} \gamma_{q}
$$

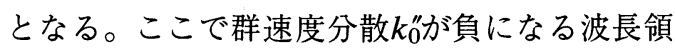
域(通常のガラスでは波長 $1.3 \mu \mathrm{m}$ より長い領域, 異常分散領域という)を考えることにする。い ま, 時間 $t^{\prime}$ をある単位時間 $\tau_{0}$ で正規化し

$$
T=t^{\prime} / \tau_{0}
$$

$z$ を $\tau_{0}$ と $k_{0}^{\prime \prime}$ で決る分散距離

$$
z_{0} \equiv \tau_{0}^{2} /\left(-k_{0}^{\prime \prime}\right)
$$

で正規化した距離

$$
Z=z / z_{0}=-k_{0}^{\prime \prime} z / \tau_{0}^{2}
$$

で表し,さらにqも $n_{2}$ で正規化した振幅

$$
Q=\sqrt{\frac{\omega_{0} n_{2} z_{0}}{c}} q
$$

で表すと

$$
\mathrm{i} \frac{\partial Q}{\partial Z}+\frac{1}{2} \frac{\partial^{2} Q}{\partial T^{2}}+|Q|^{2} Q=-\mathrm{i} \Gamma Q
$$

を得る。ここに $\Gamma$ は分散距離当りの振幅減率

$$
\Gamma=\gamma_{z_{0}}
$$

を表す。(14)式で右辺が0の場合の式のことを 非線形シュレディンガー方程式という。非線形 シュレディンガー方程式のソリトン解は振幅 $\eta$ と速度 $\kappa$ のつのパラメー夕を用い

$$
\begin{aligned}
& Q=\eta \operatorname{sech} \eta(T+\kappa Z) \\
& \quad \exp \left[-\mathrm{i} \kappa T+\frac{\mathrm{i}}{2}\left(\eta^{2}-\kappa^{2}\right) Z\right]
\end{aligned}
$$




\section{2 ソリトン発生のためのピーク電力}

誘電体の導波路の効果を考慮すると, 電場の 強度がファイバーの断面で変化することから， (9)式の非線形項の係数に約 $1 / 2$ 程度の減少係数 がかかる。また導波性から分散式(3)の $k$ にモー ド依存性が表れる。この結果 $k^{\prime \prime}$ は導波モードの 性質を表すパラメー夕，例えばファイバーの断 面の誘電率の変化などの関数となる ${ }^{13)}$ 。(11)式 の分散距離にこれを考慮した $k_{0} を$ 用い，電場の 強度分布を考慮した非線形効果の減少係数を加 味すると(13)式は

$$
Q=\sqrt{\frac{\omega_{0} n_{2} z_{0}}{2 c}} q
$$

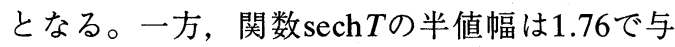
えられるから， $\tau_{0}$ をリトンの半値幅 $\tau_{s}(\mathrm{ps})$ でとると

$$
z_{0}=\tau_{s}^{2} /\left(-3.1 k_{0}^{\prime \prime}\right)
$$

と書くことができる。

それではソリトンを作るために必要な電力を 求めてみよう。振幅 $\eta=1$ のソリトン解を作る ために必要な光波の電場 $E_{0} は(17)$ 式で $Q=1, q$ $=E_{0}$ と置くことから, 光波の真空中波長 $\lambda$ を 用い

$$
\left(\pi n_{2}\right)^{1 / 2} E_{0} \tau_{s}=1.76\left(-\lambda k_{0}^{\prime \prime}\right)^{1 / 2}
$$

で表すことが出来る。光波の導波特性を考虑し た群速度分散を表すパラメー夕に群速度遅延が あり普通これを $D(\mathrm{ps} / \mathrm{nm}-\mathrm{km}) て ゙$ 表す。Dは波長 差 $1 \mathrm{~nm}$ のつの光が $1 \mathrm{~km}$ 走った後に発生する到 着時間のずれをps単位で測ったものである。導 波路の効果を考慮した群速度分散 $k_{0}^{\prime \prime}$ はを用い

$$
k_{0}^{\prime \prime}=-D \frac{\lambda^{2}}{2 \pi c}
$$

で表すことが出来る。一方ソリトンのピーク電 力を $P_{0}$ 書くと $P_{0}$ はファイバー断面積 $S$ 用い

$$
P_{0}=\frac{\varepsilon_{0}}{2} \frac{1}{k_{0}^{\prime}} E_{0}^{2} S n_{0}^{2}
$$

と書けるから $P_{0}(\mathrm{~W})$ はパルス幅 $\tau_{s}(\mathrm{ps})$ を用い

$$
\begin{aligned}
& \tau_{s}(\mathrm{ps}) \sqrt{P_{0}(\mathrm{~W})}=9.3 \times 10^{-2}\{\lambda(\mu \mathrm{m})\}^{3 / 2} \\
& \sqrt{|D|\left(\frac{\mathrm{ps}}{\mathrm{nm}-\mathrm{km})}\right) S\left(\mu \mathrm{m}^{2}\right)}
\end{aligned}
$$

と書くことが出来る。例えば, 波長 $1.55 \mu \mathrm{m}$ の 搬送波, 分散值 $|D|=1 \mathrm{ps} / \mathrm{nm}-\mathrm{km}$, 断面積 $S=60 \mu \mathrm{m}^{2}$ のファイバーを用いると(22)は

$$
P_{0}(\mathrm{~W})=\frac{1.93}{\left\{\tau_{s}(\mathrm{ps})\right\}^{2}}
$$

となる。このことはパルス幅1 psを作るのに必

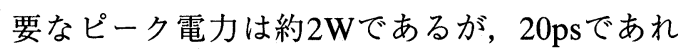

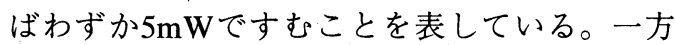
$\tau_{s}$ を大きくすると，分散距離 $z_{0}$ が大きくなり， 上記の例では $z_{0}$ は $100 \mathrm{~km}$ 以上となる。この結果 ファイバー損失率が $0.2 \mathrm{~dB} / \mathrm{km}$ の場合, 正規化 された減衰率が1を越える值となる。

\section{3. 光ソリトンの高速通信への応用}

\section{1 ソリトンの増幅と整形}

ファイバーにはレーレイ散乱などによる損失が ある。このため(14)式で示した通り, 非線形シュ レディンガー方程式は擾乱を受ける。この損乱 の大きさ $\Gamma$ はファイバーの損失率と分散率の比 $\Gamma=\gamma z_{0}=\gamma \tau_{0}^{2} /\left(-k_{0}^{\prime \prime}\right)$ 表す。このことは, ファ イバー損失はいかに小さくても, 分散距離 $z_{0}$ の 大きいパルス，すなわち，パルス幅が大きいソ リトンを用いると「が1を越えることを示して いる。「が1を越えると(14)式のソリトン解は 存在しなくなる。従って, ソリトンが作られる ためには， $\Gamma \ll<1$ 条件を必要とする。ファ イバー損失は光の波長が $1.55 \mu \mathrm{m}$ あたりで最小

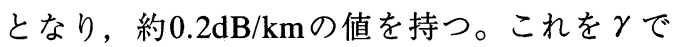
表すと, $\gamma \approx 2.4 \times 10^{-1} \mathrm{~km}^{-1}$ となる。この損失 の值はほとんど理論的極限值であるため, これ に比べ $\Gamma$ 小ささなることは望めない。となる と $\Gamma \ll<1 の$ 条件を満たすためには, 分散距離 $z_{0}$ が $40 \mathrm{~km}$ であることが要求される。一方 $z_{0}$ は 分散パラメータおよびパルス幅を用い

$$
z_{0}=\frac{\tau_{s}^{2}}{-3.1 k_{0}^{\prime \prime}}=6.1 \times \frac{10^{8} \tau_{s}^{2}}{|D| \lambda^{2}}
$$


と表される。ここで $\tau_{s} を \mathrm{ps}, \lambda を \mu \mathrm{m}, D$ を $\mathrm{ps} / \mathrm{nm}-\mathrm{km}$ の単位で表すと,

$$
z_{0}(\mathrm{~km})=0.61 \frac{\tau_{0}^{2}(\mathrm{ps})}{|D|(\mathrm{ps} / \mathrm{nm}-\mathrm{km}))\{\lambda(\mu \mathrm{m})\}^{2}}
$$

となる。このことは $|D|=1 \mathrm{ps} / \mathrm{nm}-\mathrm{km}, \lambda=$ $1.55 \mu \mathrm{m}$ の場合, $z_{0}(\mathrm{~km})=0.25\left\{\tau_{s}(\mathrm{ps})\right\}^{2}$ となり,

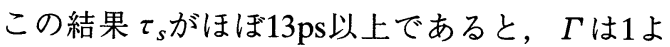
り大きくなり,ソリトンは作られないことがわ かる。

しかし, もし光増幅器をファイバー線路に組 み込むことにより，実質的に $\Gamma$ 小さくするこ とが出来ると, この問題は解決する。それには $2 つ$ 方法がある。ひとつは増幅率 $\gamma_{g}$ を充分小

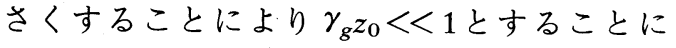
よって増幅による損乱を小さくする方法であ る。これを断熱的増幅と名づけよう。もうひと つは $\gamma_{g} z_{0} \gg 1$ すなわち, 局所的に急激に増幅 する方法である。これを非断熱的増幅と呼ぶこ とにしよう。断熱的増幅または減衰の場合, (16)式のソリトン解はソリトン振幅 $\eta を$

$$
\eta=\eta_{0} \exp (-2 \Gamma z)
$$

で置き換えることにより成立する。減衰率も増 幅率も断熱的である場合, 減衰領域ではソリト ンは振幅を(24)式に従ってゆるやかに減少し, 同時にパルス幅は増大しながら伝搬する。続い て, 増幅領域では振幅は増大し，パルス幅は減 少するいずれの領域でも振幅とパルス幅の積 は一定に保たれる。これをソリトンの断熱変化 という。

次に, 減衰が断熱的であっても増幅器が非断 熱的である場合を考えると，これは(24)式に 従って減少した振幅を局所的に増大させること になるから，仮にこの結果，振幅を元通りの大 きさまで修正出来たとしても，パルス幅はそれ に応じて断熱的に狭まることが出来ないため, 増幅器を通過した後のパルスは元のソリトンで はなくなってしまう。

もし減衰も非断熱的, 増幅も非断熱的であれ
ば，(14)式は至るところソリトン解を持たなく なってしまう。しかし, 非常に興味深いことに, こうした場合でもソリトン解が得られること

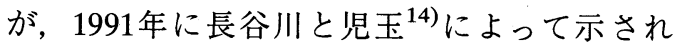
た。これがガイディングセンターソリトンの考 えである。

\section{2 ガイディングセンターソリトン}

ソリトンの長距離伝送を行う場合, 非線形効 果を維持するためには光波の振幅をある值に 保っておく必要がある。このため, ファイバー 損失を補うだけの光増幅を繰り返して行わねば ならない。光増幅は普通, 非断熱的に行われる ため, 増幅器を通過した後の光パルスはパルス 幅の変化はなく，振幅だけが大きくなる。この 結果増幅器を通過した後の光パルスは, 以前の ソリトンとは別のソリトンになってしまう。し かし, 新しいソリトンが実際作られ, 同時に分 散性を持つ線形波動が発生するためには，少な くとも分散距離 $z_{0}$ だけ進まなければならない。 従って，もし $z_{0}$ よりも短い距離で再び増幅をし てやると, 発生した非断熱増幅から発生する線 形波動もパルスの中に取り込んでしまうことが 可能ではないかと考えられる。もちろん，この 場合増幅率はこの間のファイバー損失をちょう ど補うだけの值にしておかなければならない。 長谷川と児玉は， $\Gamma>1$ でソリトン解が存在 しないにもかかわらず，減衰と増幅により，短 い間隔で激しい周期的擾乱を受けた非線形シュ レディンガー方程式から，どのような形でソリ トン解が作られるかを考察し, この結果, 擾乱 を受けた非線形シュレディンガー方程式を， リー変換により擾乱をほとんど伴わない非線形 シュレディンガー方程式に変換出来ることを示 し，このような形で作られるソリトンを，磁場 中の荷電粒子の運動との類似性から, ガイディ ングセンターソリトンと名づけた ${ }^{14)}$ 。

\section{3,3 ソリトンの伝送制御}

ソリトンを通信に用いる場合の大きな問題 は,ソリトンの位置が伝送途中に変動すること 
である。ソリトンは，その性質から波形そのも のは安定であるが, ソリトンの位置をロックす る機構をもたないため, 増幅器の雑音で周波数 変調を受けたりするとソリトンパラメータ

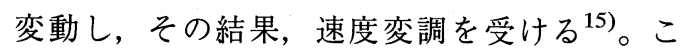
の問題を解決するため長谷川と児玉 ${ }^{16)}$ は, 狭 帯域フィルターとEDFAを組み合わすことによ り狭帯域増幅器を作り,これによってソリトン の振幅 クおよび速度 $\kappa$ を，ある值にロックする ことを提案した。Mollenauerはこの考えをた だちに採用し， $10 \mathrm{~Gb} / \mathrm{s}$ の伝送実験に成功し た ${ }^{11)}$ 。Mecozzi ${ }^{17)}$ ち同じ頃, 同様の考えを提 唱している。

狭帯域フィルターの中心周波数を, ソリトン の搬送波の周波数 $(\kappa=0)$ に合わせ，この周波 数での増幅率の利得をファイバー損失より $\delta(>0)$ だけ多くし，またフィルターの曲率 $\partial^{2}$ $\delta / \partial \omega^{2}$ を $\beta(<0)$ とすると, ソリトンパラメー 夕(振幅 $\eta),($ 速度 $\kappa)$ は $\eta-\kappa$ 面で $\eta=\sqrt{-3 \delta / \beta}$ および $\kappa=0$ に収斂することが示される。これ はソリトンの持つ非線形な性質からくる性質で ある。例えば，もし $\kappa \neq 0$ の点から出発すると， この点での利得は最大利得より小さいため, ソ リトンの中心周波数は利得が最大となる $\kappa=0$ に動かされる。しかし, ソリトンの振幅は $\kappa=$ 0で限りなく増大することはない。それはソリ トンの振幅が大きくなると(16)式からわかるよ うにパルス幅が小さくなり，スペクトルが拡が る。すると, フィルターの効果が効いてスペク トルの両端をカットするため, ソリトンのエネ ルギーは減少するからである。一方， $\delta>0$ の 周波数帯域の線形波は, このような性質を持た ないから，不安定となって Zと共に増大する。 このため長距離にわたって安定なソリトン通信 を達成するためには，この線形波を取り除いて やらなければならない。この方法については, 次節で述べる。

3.4 ソリトンを用いた信号と雑音の分離 ソリトンを通信に用いると，線形波動では得ら れない興味ある特徵として, 信号と雑音を分離
することが出来る。これは一般にソリトンが線 形波動とは異なった速度で進むからで, この性 質を用いると初期にソリトン信号と雑音が, た とえ同じ周波数に混在していても，伝送ととも にソリトン信号は雑音と時間的に分離するた め, 雑音成分を除去することが出来る。特にガ イディングセンターソリトンの例のように, 増 幅を繰り返して行った場合には, 雑音が重畳し てくるため, SN比が増幅器の数に比例して低 下することが起こるが, こうしたソリトンの性 質を用いるとSN比の劣化を防ぐことができる。 例えば, Mollenauerはソリトン伝送制御用の フィルターの中心周波数を, 各増幅器で少しず つずらすことにより, 信号と雑音の分離に成功 している ${ }^{12)}$ 。またファイバーの持つ高次の分 散効果 $k_{0}^{\prime \prime \prime}$ を加味すると, ソリトン速度 $v$ は

$$
v=\frac{k^{\prime \prime \prime} z_{0}}{6 \tau_{0}^{3}} \eta
$$

で与えられることが示され，振幅 クに比例して 速度が遅くなることが示される。またファイ バーの持つラマン効果を考慮すると, ソリトン の速度 $\kappa$ は振幅の4乗に比例して次式の示す通 り減少することが示される。

$$
\frac{\partial \kappa}{\partial Z}=-\frac{8}{15} \frac{\lambda}{\pi n_{2} \tau_{0}} \frac{\partial \gamma_{R}}{\partial \omega} \eta^{4} .
$$

ここに $\gamma_{R}$ はラマン増幅率を表す。

これらの効果を利用すると, 線形波動の速度で 進む雑音と振幅に依存して進むソリトンは, 時 間的あるいは周波数的に分離し, 適当な周波数 フィルターやクロックを用いることにより,ソ リトン信号だけを取り出すことが可能になる。

\section{4. 結論}

ファイバー中の光ソリトンの発見から, ほぼ 20 年以上の月日が経った。この間, 低損失ファ イバーの開発, 低損失領域で発信する半導体 レーザーの出現, EDFA光増幅器の発明等, ソ リトン通信にとって幸運な発見が次々となされ た。また, 非断熱領域で繰り返し増幅をした場 
合の, ソリトンの振舞を記述するガイディング •センター・ソリトンの理論, さらにソリトンの 速度と振幅をロックするソリトンの伝送制御理 論, ソリトン信号と雑音の分離など, 当初の単 純なソリトン理論に比ベソリトン通信を実現す るための画期的な理論が展開された。この結果, ソリトンの高速通信への実用化は間近にせまっ ている。実際1993年には, ソリトンを用いた長 距離通信の実験で, 通信速度と通信距離で20 $\mathrm{Gb} / \mathrm{s}, 1300 \mathrm{~km}$, 両方とも従来方式の記録を 更新した。今後期待されるソリトン通信の方向 には2つある。ひとつはMollenauerらが示した ように，波長分割多重方式の開拓である。 EDFAの利得の中に入る波長帯をフルに利用し た波長分割多重通信が考えられ，例えば， $10 \mathrm{Gbit} / \mathrm{s} \times 8$ チャンネル $=80 \mathrm{Gbit} / \mathrm{s}$ 程度までの 通信速度が可能と思われる。ソリトンを用いた 波長分割通信のもうひとつの利点は，3.3節で 示した自己形成の性質を用いることにより，各 チャンネルの中心周波数で利得がピークを保つ ようなフィルターを用いると，各チャンネルの 利得を全く同值にする利得コントロールを必要 としない点だ。これは利得にバラつきがあって

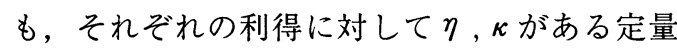
を持つからだ。

将来のソリトン通信が目指すことが出来るも うひとつの方法は, サブピコ領域の極超短パル スでソリトンを作り，断熱方式により1チャン ネル $1 \mathrm{~Tb} / \mathrm{s}$ 領域の通信を行うことだ。この場合 には数千キロメートルの長距離は難しいが, 数 十ないし数百キロメートルの短距離の超高速通 信としての利用が考えられる。

光ソリトンはその振舞が理論とよく合うとい う点で他に例を見ない。他の物理や工学の分野
からも注目を集めている。このため, ソリトン 通信の発展は通信分野だけでなく, 他の多くの 分野に大きなインパクトを与えている。

\section{参 考 文 献}

1) A. Hasegawa and F. Tappert: Appl. Phys. Lett. 23 (1973) 142.

2) V. E. Zakharov and A. B. Shabat: Sov. Phys. JETP 34 (1972) 62.

3) L. F. Mollenauer, R. H. Stolen, and J. P. Gordon: Phys. Rev. Lett. 45 (1981) 1095.

4) Y. Kodama and A. Hasegawa: Opt. Lett. 7 (1982) 339.

5) A. Hasegawa: Opt. Lett. 8 (1983) 650.

6) A. Hasegawa: Appl. Opt. 23 (1984) 3302.

7) R. J. mears, L. Reekie, I. M. Jauncey, and D. N. Payne: Electron. Lett. 23 (1987) 1026.

8) E. Desurvire, J. R. Simpson, and P. C. Beeker: "High-Gain Erbium-Doped Traveling-Wave Fiber Amplifier", Opt. Lett. 12 (1987) 888.

9) M. Nakazawa, Y. Kimura, and K. Suzuki: Electron. Lett. 25 (1989) 199.

10) M. Nakazawa, E. Yamada, H. Kubota, and K. Suzuki: Electron. Lett. 27 (1991) 1270.

11) L. F. Mollenauer, E. Lichtman, G. T. Harvey, M. J. Neuvelt, and B. M. Nyman: Electron. Lett. 28 (1992) 792.

12) L. F. Mollenauer, E. Lichtman, M. J. Neubelt, and G. T. Harvey: OFC '93 Post deadline paper (1993).

13) Y. Kodama and A. Hasegawa: IEEE J. Quantum Electron. QE-23 (1987) 510.

14) A. Hasegawa and Y. Kodama: Opt. Lett. 15 (1990) 1443, Phys. Rev. Lett. 66 (1991) 161 and Opt. Lett. 16 (1991) 1385.

15) J. P. Gordon and H. A. Haus: Opt. Lett. 11 (1986) 665.

16) Y. Kodama and A. Hasegawa: Opt. Lett. 17 (1992) 31.

17) A. Mecozzi, J. D. Moores, H. A. Haus, and Y. Lai: Opt. Lett. 16 (1991) 1841. 